\title{
Agri Skill India-Desires Instantaneous Upgrading for Livelihood Security
}

\author{
Ghosh RK*, Ghosh A and Mondal D \\ Department of Agronomy, Bidhan Chandra Krishi Viswavidyalaya (BCKV), India
}

Submission: October 26, 2016; Published: November 14, 2017

"Corresponding author: Ghosh RK, Department of Agronomy, Bidhan Chandra Krishi Viswavidyalaya (BCKV), India, Tel: 91-9433145340;

Email: drajr1956@gmail.com

\section{Mini Review}

The demand for food, oil and processed commodities is increasing due to growing population and rising per capita income. Global food demand is expected to be doubled by 2050 while production environment and natural resources are continuously shrinking and deteriorating. Food and oil crisis has aggravated further because of climate change and diversion of arable lands to urbanization, industrialization and also for producing bio-fuel. There are projections that demand for food grains in India would increase to $345 \mathrm{~m}$ in 2030 hence productivity of food grains and oilseeds need to be increased in a sustainable manner which a challenge to agriculturists as the present food grain and oilseeds production is estimated to $273 \mathrm{~m}$ and 33m, respectively (ICAR, Vision 2030).

System of Intensification, the best management practices with what farmers have, is the preeminent alternative methodology in such situation to increase productivity in a sustainable manner as this methodology is depending on more and more biological management changing from present chemical dependence in agriculture and allied sectors. The system intensification depends largely on improving soil and plant health by farmers improves thinking. Field agriculture in India is still managing by farmers and majority of them are not professionally educated in agriculture as like the agricultural graduates but only having experience of cultivation.

Look at the population of India that is now around 1.30 billion and estimates showed that it has a significant demographic dividend with more than $62 \%$ population between $15-59$ years of age. Globally, in the next 20 years, the industrial workforce is expected to decline by $4 \%$, whereas in India, it is expected to grow by $32 \%$. Around 250 million people are estimated to enter the Indian labour market by 2025 (India Skills Report, 2016) and only 5\% of the young people aged 20-24 have obtained vocational skills through formal training system by various State and Central Agricultural Universities and Directorates of Agriculture, (SAU, CAU, DAC etc.), Industrial Training Institutes
(ITIs) and Industrial Training Centre (ITCs) but these are not sufficient to meet the huge and diverse skill requirement of the assorted population.

The major sustainable production technology is on food crop and oilseed, horticulture and seed production and the scientific researches are based on farmers acceptance and generated technologies are transferring to farmers through awareness programmes (Figure 1). There is an urgent need for academia, scientists, policy makers and various organizations to join hands, pool in resources, share expertise to create a sustainable operational framework that will form a bigger impact in skill sector towards overcoming the wide challenges. At SAU, CAU, ICAR Institutions, DAC, NABARD and NGOs mostly training and awareness programmes are organized to aware the farmers about improving the skills keeping parity with modern agricultural problems and prospects. Thus, a sustainable outlook with universal and lifelike needs to be implied to endorse all corners of our innocuous social and environment life status for our diverse societies.

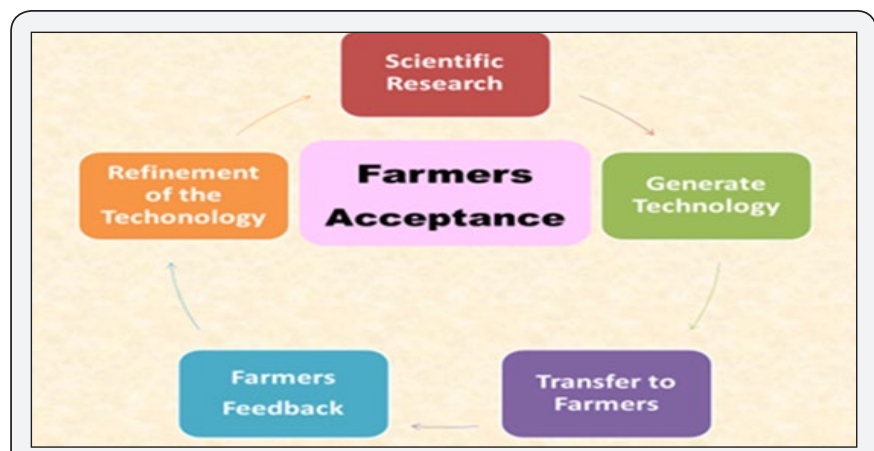

Figure 1: Finding problems and future solutions.

The thoughtful sustainability demands new innovations and brink acerbic products but it rests largely on capacity building, justifiable strategy and social employability. The classical example is invasive pests and biodiversity change (the invasive 
weed Parthenium hysterophorus entered in India through food grains, initially located roadsides and wastelands but entering crop fields). Unless the social people will join in this programme it is very difficult to manage the invasive pests and also the to reduce the sudden biodiversity change. For nations food and oil security it needs improving sustainable production, the concept is (i) use of farmers' available resources and for this the task of agricultural scientists, officers and industries are to create more available resources along with improving the skilling of farmers for better use these resources and (ii) farmers economic benefits i.e. invested amount should back to farmers with a profit at earliest.

The management of land and seed (that can able to increase production at least by $10 \%$ ) is the prime objective followed by pest management (production improvement by around 20\%) and for sustainable production improvement use of balance nutrition, diversification of crops with more legumes, judicious water use are some important measures. For quality product assurance and more profit use of more bio-chemicals rather than synthetic chemicals are necessary.

More agriskilling of rural youths is needed in the following aspects

a. Conservation agriculture benefits for saving soil erosion loss, timely sowing with optimum population, better use of residue recycling \& residual moisture and reduce cultivation cost. Training should be given on importance of minimal or zero tillage with weed management.

b. The improve management for improving plant health the use of basic input seed should be farmers' own viable and $100 \%$ pure (this will reduce invasive pest problems), seed treatment including seed priming and protection against soil \&seed borne pests (this will reduce pest problems), time of planting with proper plant population, use of balance nutrition instead of more biasness on nitrogen fertilizer use, judicious water use as needed in crops' critical physiological stages and ecosafe pest and quality management.

It has been observed that besides the SAUs, ICAR Institutions and Government organizations some NGOs are also coming forward to skill analysis development status programme(example Global Hunt Foundation launched "Skill India-Enhancing Capabilities, Empowering Lives" at Kolkata Gateway Hotel on September 15, 2017. The notable participants for group discussion on this issue were CEO of Capital Goods Skill Council, eminent agriculturist from BCKV, economist from IIM, founder of school of entrepreneurial exploration, Secretary, help missions, Indian feminist NGO, Head, CSR, Castrol India, GM, Skill training ACF and some other head NGOs. The major advantage of skilling rural youth is to generate employment opportunities).
The major outlook of Skill India programme is (i) how to achieve the national vision, (ii) role of agricultural universities, NABARD, NGOs, different types of non-financial and financial partnershipspublic-private including partnerships-the value each stakeholder and lastly building blocks for partnerships-open communication, trust, understanding of core competencies and opportunities created by government to facilitate such engagements.

It has been estimated that 15 million youth/annum enter the workforce but around $75 \%$ of them are not 'job ready' and only around $2 \%$ is undergoing some skill training. It is well known that we are forwarding towards the post 2015 development wherein the entire development paradigm is witnessing a major change in this aspect. A sustainable outlook includes holistic and universal but realistic considering the social, economic and environment in equal share. In India the skill for enterprise building programmes may be encouraged with priority on vertical farming, terrace garden, mushroom, honey bee, parthenium or vermi-composting, floriculture, fishery, fruit preservation etc. (Figure 2). Under my research guidance some innovative approaches have already been developed by working at West Bengal with farmers and some of these are making compost from invasive weed plant Parthenium hysterophorus, rice growing with $30 \%$ less water, use of water submerged tolerant verities replacing traditional local varieties in flash flood areas, using of fruit gardens with diversification of crops etc.

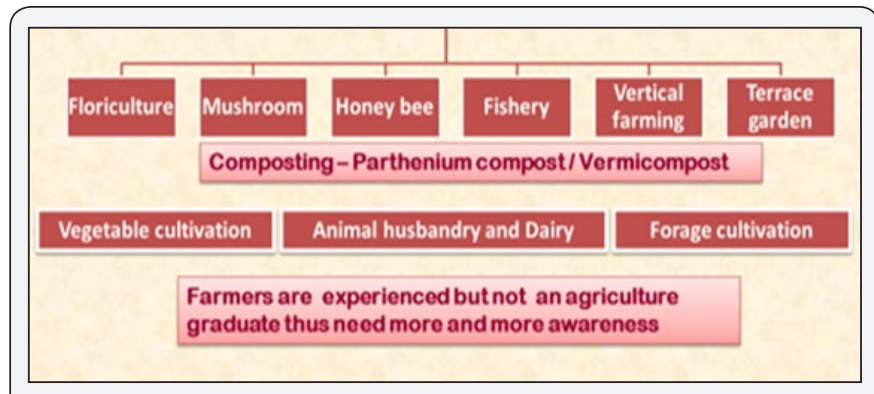

Figure 2 : Enterprise building: skill.

Therefore, for sustainable life it needs sustainable supply of food, capital and future development of society. The NGOs and corporates has also the social responsibility besides the Government institutions and organizations. For skill improvement nevertheless, it needs at initial to motivate youth into skilling by using their aspiration form their present interest on white collar professional jobs for which they are migrating from rural to urban, instead of skill based jobs that is the liking of employers on the major aspects of the high-quality livelihood, address market demand, fostering entrepreneurship, biological agriculture programmes in new forms of innovations and knowledge. It should always be kept in mind that poor governance and insecurity can all too easily undermine progress on economic, social and environmental objectives. 
Your next submission with Juniper Publishers will reach you the below assets

- Quality Editorial service

- Swift Peer Review

- Reprints availability

- E-prints Service

- Manuscript Podcast for convenient understanding

- Global attainment for your research

- Manuscript accessibility in different formats

( Pdf, E-pub, Full Text, Audio)

- Unceasing customer service

Track the below URL for one-step submission https://juniperpublishers.com/online-submission.php 